PAWEL BERNACKI

Instytut Informacji Naukowej i Bibliotekoznawstwa

Uniwersytet Wrocławski

\title{
LITERACKIE ŻYWE BIBLIOTEKI A ICH RZECZYWISTE ODPOWIEDNIKI. ANALIZA WYBRANYCH PRZYKŁADÓW
}

Słowa kluczowe: biblioteka, topos, żywa biblioteka, żywa księga

Keywords: library, topos, human library, human book

\section{HUMAN LIBRARIES IN LITERATURE AND REALITY. ANALYSIS OF SELECTED EXAMPLES}

\section{Sum m ary}

The text focuses on the subject of human library. The first part of the article analyses literary realisations of this motif in the works of such writers as: Ray Bradbury, Jorge Luis Borges, Thomas Wharton, and Walter Moers. Next, the author focuses on human libraries existing in our reality. Finally, those two aspects of the discussed phenomenon are confronted with each other to show how capacious the terms 'book' and 'library' have become.

\section{Wstęp}

Krystyna Bednarska-Ruszajowa, badając motyw biblioteki w literaturze polskiej, odnalazła trzysta dwadzieścia pięć utworów, w których pełni on mniej lub bardziej istotną rolę. W zebranym przez nią materiale odnaleźć możemy stworzone przez stu pięćdziesięciu ośmiu pisarzy ujęcia księgozbiorów prywatnych $\mathrm{i}$ instytucjonalnych. Autorka oprócz opisania funkcji, jakie pełnią w danych dziełach, przedstawiła je także w ujęciu metaforyczno-symbolicznym, jako „wzorcowe, modne, nielegalne, unicestwione i inne" ${ }^{\text {. }}$ W jej przeglądzie nie zabrakło i wzmianek dotyczących wizerunku bibliotekarza. Tak szerokie spojrzenie na omawiany

\footnotetext{
${ }^{1}$ Krystyna Bednarska-Ruszajowa, Biblioteki w literaturze polskiej (Kraków: Wydawnictwo Uniwersytetu Jagiellońskiego, 2006).

${ }^{2}$ Ibidem, 16.
} 
problem sprawia, że zgromadzony przez Bednarską-Ruszajową zbiór jawi się jako kompletny. Gdzieś obok ścisłych zainteresowań badaczki dryfuje jednak jeszcze jeden, niezwykle specyficzny typ księgozbioru, o którym ta nie wspomina - złożony z żywych ksiąg. Bazując na poczynionych przez autorkę ustaleniach na temat rodzimych prac nad omawianym tematem oraz stworzonej przez nią bibliografii Światowych badań nad opisami bibliotek $w$ utworach literackich ${ }^{3}$, można stwierdzić, że motyw żywego księgozbioru nie przyciąga uwagi naukowców zajmujących się toposem biblioteki, a rzadkie wzmianki na jego temat to raczej zauważenie problemu niż jego analiza ${ }^{4}$. W tym miejscu tworzy się więc pewna luka, którą warto wypełnić, szczególnie że wątek human library jest nie tylko literackim tworem, ale posiada także swoje realne odbicie. I to właśnie owe rzeczywiste realizacje - w konfrontacji z wybranymi pomysłami pisarzy - stanowią przedmiot analizy niniejszego szkicu.

\section{Żywe biblioteki jako temat literacki}

Mówienie o każdej bibliotece (a więc także żywej) wedle tezy zawartej w jednym z esejów Umberto Eco, powinno się zaczynać od lektury Księgi, pisanej wielką literą, świętej. Czynność ta ma celu pomoc w osiągnięciu odpowiedniego stanu ducha, wejściu we właściwy, podniosły nastrój. Za ów sakralny tekst włoski erudyta uważał słynne opowiadanie Jorge Luisa Borgesa zaczynające się powszechnie znanym cytatem porównującym wszechświat do księgozbioru ${ }^{6}$. Ogrom stworzonej przez argentyńskiego pisarza wizji może przytłaczać. Biblioteka Babel jest nie tylko wielka, ale również tajemnicza, w dużej mierze zakryta. Stanowi nieprzeniknioną kombinację ścieżek, pomieszczeń, schodów, ale także języków, szyfrów i oczywiście książek. Żaden z jej pracowników nie jest w stanie nad nią zapanować, skatalogować jej. I to w żadnym stopniu nie powinno dziwić - jej zbiory są nieprzebrane, nie ma wśród nich takich samych egzemplarzy, dwóch identycznych dzieł. Księgi składają się z podobnych elementów, ale się nie powtarzają:

${ }^{3}$ Eadem, Światowe badania nad opisami bibliotek w utworach literackich, in Biblioteki i ksiażki w literaturze, ed. Krystyna Bednarska-Ruszajowa (Kraków: Wydawnictwo Uniwersytetu Jagiellońskiego, 1998), 9-54.

${ }^{4}$ Wzmianka o żywym księgozbiorze pojawia się m.in. w artykułach: Marzeny Kowalskiej i Jerzego Kałążnego. Marzena Kowalska, Kształtowanie wizerunku biblioteki w literaturze pięknej, in Kształtowanie wizerunku biblioteki, ed. Maria Czyżewska (Białystok: Wydawnictwo Wyższej Szkoły Ekonomicznej w Białymstoku, 2007), 105-132; Jerzy Kałążny, „Motyw biblioteki w literaturze", Biblioteka, no. 2 (1998): 5-14.

${ }^{5}$ Umberto Eco, O bibliotece, trans. Adam Szymanowski (Warszawa: Świat Książki, 2007), 5.

${ }^{6}$ Jorge Luis Borges, Biblioteka Babel, in Fikcje, trans. Kazimierz Piekarec, Andrzej Sobol-Juszczykowski (Warszawa: Państwowy Instytut Wydawniczy, 1972), 65. 
Biblioteka jest totalna. Jej szafy rejestrują wszelkie możliwe kombinacje tych dwudziestu kilku symboli ortograficznych (liczba ich, choć niezwykle wysoka, nie jest nieskończona), to jest wszystko to, co można wyrazić: we wszystkich językach. Wszystko: drobiazgową historię przyszłości, autobiografie archaniołów, wierny katalog Biblioteki, całe tysiące fałszywych katalogów, wykazanie fałszywości tych katalogów, wykazanie fałszywości katalogu prawdziwego, gnostyczną ewangelię Bazylidesa, komentarz do tej ewangelii, prawdziwą relację twojej śmierci, przekłady wszystkich książek na wszystkie języki, interpolacje z każdej książki we wszystkich książkach?

Biblioteka jest wszystkim, zawiera w sobie wszystko, każdą książkę, jaką może sobie wyobrazić człowiek, a zapewne znacznie więcej. W cytowanym opowiadaniu Borges - będący niezrównanym mistrzem w tworzeniu oryginalnych, fantazyjnych pomysłów na woluminy (by wspomnieć tu tylko o pozbawionej początku i końca Księdze Piasku) - przedstawia ideę człowieka-księgi. Wielkiego bibliotekarza, któremu, jako jedynemu, udało się przeczytać tajemnicze dzieło, będące esencją wszystkich innych. Uzyskane w ten sposób wiedza i moc sprawiły, że doczekał się własnego kultu i urósł do rangi boga:

W pewnej szafie pewnego sześcioboku (rozumowali ludzie) musi istnieć jakaś księga, która jest doskonałą esencją i kompendium wszystkich pozostałych: jakiś bibliotekarz przeczytał ją i podobny jest bogu. W języku tej okolicy przetrwały jeszcze pozostałości kultu tego odległego urzędnika. Wielu ludzi odbywało pielgrzymki w Jego poszukiwaniu. W ciągu stulecia nużyli daremnie najprzeróżniejsze kierunki ${ }^{8}$.

Akt lektury był dlań przynajmniej częściowym przeistoczeniem się w księgę, który to proces - na wzór ukutej przez Sebastiana Kotułe „książkowatości” - pozwolę sobie nazwać „uksiążkowieniem”. O ile pierwszy z tych terminów stanowi zespół cech, jakie musi mieć przedmiot, by móc stać się książką, o tyle drugi proponuję rozumieć jako nabieranie tychże wartości. W przypadku tekstu Borgesa ów akt nosi znamiona deifikacji, urośnięcia do rangi wyższych bytów - bóstw. Treść potężnej księgi zawładnęła jestestwem czytającego, wyniosła je na niespotykane dotąd poziomy. Dla człowieka złaknionego wiedzy - a takim musiał być wspomniany w cytacie bibliotekarz - to wydarzenie, posiadające rysy epifanii, stało się błogosławieństwem, być może osiągnięciem wymarzonego celu. Uksiążkowiony człowiek pojmowany jako potencjalne bóstwo to jednak stosunkowo rzadkie ujęcie motywu ludzkiej księgi. Na kartach powieści częściej można spotkać się z sytuacją, gdy akt przeistoczenia się w książkę okazuje się koniecznością. Stworzone przez literatów żywe biblioteki to raczej przykłady walki o ocalenie od zapomnienia niż poszukiwań mocy.

${ }^{7}$ Ibidem, 68-69.

${ }^{8}$ Ibidem, 71 .

${ }^{9}$ Sebastian Kotuła, Komunikacja Bibliologiczna wobec World Wide Web, rozprawa doktorska (Warszawa 2012), http://depotuw.ceon.pl/bitstream/handle/item/189/Komunikacja\%20bibliologiczna $\% 20$ wobec $\% 20$ World $\% 20$ Wide $\% 20$ Web.pdf? sequence $=1$ (acc. 05.01.2018). 
Najsłynniejszą realizację omawianego motywu możemy odnaleźć w dystopii Raya Bradbury'ego 451 stopni Fahrenheita. W świecie, gdzie czytanie książek jest surowo zabronione, a straż pożarna zajmuje się paleniem lektur, po bezdrożach snują się tajemnicze grupki banitów, których życiowym celem jest uczenie się na pamięć tekstów dzieł literackich i filozoficznych. Gdy spotka ich główny bohater powieści - Montag - przedstawiają się następująco:

Poznaj także Jonathana Swifta, autora nikczemnej politycznej powieści Podróże Guliwera! A ten facet obok to Charles Darwin. To Schopenhauer, to Einstein, a ten koło mnie to pan Albert Schweitzer, nad wyraz życzliwy filozof. Jesteśmy tu wszyscy Montag: Arystofanes i Mahatma Gandhi, Gautama Budda i Konfucjusz, Thomas Love Peacock i Thomas Jefferson, a także pan Lincoln, do usług. Jesteśmy też Mateuszem, Markiem, Łukaszem i Janem. [...] Tysiące. Na drogach, wzdłuż opuszczonych torów, włóczędzy na zewnątrz, biblioteki wewnątrz. Początkowo nie planowaliśmy tego. Każdy miał jakąś książkę, którą chciał zapamiętać i udało mu się. Potem przez jakieś dwadzieścia lat spotykaliśmy się w drodze, stworzyliśmy luźną siatkę i obmyśliliśmy plan. Najważniejsze, co musieliśmy sobie wbić do głów, to że nie jesteśmy ważni, że nie możemy być pedantyczni, nie wolno nam wywyższać się ponad nikogo innego. Jesteśmy tylko obwolutami książek; poza tym nic nie znaczymy ${ }^{10}$.

Przywołani powyżej wędrowcy zatracają swoją osobowość na rzecz tekstów literackich. Grupa ludzi stopniowo przeistacza się w zbiór chodzących ksiąg - żywą bibliotekę. Nie zwracają się do siebie prawdziwymi imionami i nazwiskami, lecz tytułami dzieł bądź personaliami ich autorów. Ich cechy dystynktywne, osobowe, indywidualne są wypierane przez treść lektur, którymi się stają. Sami nazywają się obwolutami, stwierdzają, że nic poza tym nie znaczą - ich ciała to pojemniki na teksty. Moglibyśmy powiedzieć, że są czymś na wzór chodzących i oddychających audiobooków. Co wydaje się interesujące, swoje przeistoczenie członkowie opisywanej organizacji nazywają „zmartwychwstaniem”. „Witamy po zmartwychwstaniu" - właśnie tak zwracają się do Montaga, gdy przyjmują go w swoje szeregi. W ich przypadku nie mamy jednak do czynienia z powrotem do życia, a raczej z całkowitą zmianą własnej egzystencji i wyrzeczeniem się samego siebie. Uksiążkowienie polega tutaj nie na deifikacji, lecz zrzeczeniu się tożsamości, rezygnacji $\mathrm{z}$ własnego ja i staniu się pojemnikiem na tekst literacki, który w mrocznym świecie powieści Bradbury'ego okazuje się wyższą wartością niż jednostkowa egzystencja.

Celem tej specyficznej biblioteki jest ocalanie od zapomnienia, ratowanie dziedzictwa ludzkości zapisanego w książkach. Jej członkowie będą przechowywać teksty w sobie, dopóki nie nadejdą lepsze czasy i nie będą mogli ponownie zwrócić ich papierowi. Można w tym momencie postawić pytanie, jaki los spotka wtedy członków omawianej organizacji? Czy będą w stanie wrócić do swoich tożsamości? A może na zawsze pozostaną owymi obwolutami książek, tym razem

${ }^{10}$ Ray Bradbury, 451 stopni Fahrenheita, trans. Iwona Michałowska-Gabrych (Warszawa: Solaris, 2008), 193-194. 
jednak pozbawionymi nadającej sens ich istnieniu ochronnej funkcji? Abstrahując jednak od tych niedających się rozstrzygnąć kwestii, należy zauważyć, że żywa biblioteka z powieści Bradbury'ego jest w jakiś sposób ułomna. Mimo świetnej organizacji, pozwalającej jej przetrwać w nieprzyjaznym świecie, zbiory, które gromadzi, są, delikatnie mówiąc, niekompletne. Rządzi nimi raczej chaos niż ład. Kolejne tytuły pochodzą z najróżniejszych epok, nie są właściwie dobrane, opisane, skatalogowane. O dołączeniu nowych tekstów do kolekcji decyduje przypadek - to, kogo akurat spotka się na trakcie i czy ta osoba będzie znała na odpowiednim poziomie jakieś dzieło literackie, czy będzie gotowa się w nie przeistoczyć. Co więcej, sama treść kolejnych żywych książek w zbiorze zależy od ludzkiej pamięci, a więc jest w jakiś sposób niepewna i niemal niemożliwa do zweryfikowania, narażona na zapominanie, a co się z tym wiąże całkowite zniknięcie. Tytuły znajdujące się w tym specyficznym księgozbiorze to często tylko wyimki, fragmenty, ułomki - niewielki skrawek tego, co pozostało po ogromnym literackim dziedzictwie ludzkości. Książki zniknęły w kolejnych pożarach. To, co po nich pozostało, to właśnie owi snujący się po gościnach banici, ceniący wyżej niż własne życie misję przechowania dla przyszłych pokoleń choćby skrawków dawnej chwały. Uksiążkowanie jest dla nich koniecznością, ideą nadająca sens życiu. Przeistaczają się w kolejne książki, bo akt ten daje im nadzieję na lepsze jutro. Wolą istnieć jako niepełny, wybrakowany egzemplarz, na przykład, Podroży Guliwera, niż pozwolić temu dziełu bezpowrotnie przepaść.

W nieco inny sposób do problemu żywej biblioteki podszedł Walter Moers w swoim Mieście Śniących Książek - powieści, w której niemal wszystko wiąże się z księgami i szeroko rozumianym życiem literackim. Camonia - świat, w jakim toczy się przedstawiona historia - to kraina, gdzie dosłownie każdy mieszkaniec nałogowo czyta. Spotkania autorskie przyciągają rzesze ludzi, księgarnie pękają w szwach, pisanie to najlepsze z możliwych zajęć, a trudno dostępne egzemplarze niektórych dzieł osiągają na aukcjach niebotyczne wręcz ceny. Co więcej, w powieści pojawia się ogrom niezwykle oryginalnych pomysłów na książki. W barwnym korowodzie wymyślanych przez Moersa ksiąg pojawia się również motyw żywej biblioteki. Stanowią ją członkowie tajemniczej rasy buchlingów. Jej przedstawiciele od najmłodszych lat uczą się na pamięć twórczości danego pisarza, by w finalnym rozrachunku stać się czymś na wzór żywego wydania jego dzieł zebranych. Sensem życia tych stworów jest więc nieustanna nauka na pamięć poematów i powieści, całkowite poświęcenie studiowaniu dorobku danego autora.

Każdy buchling uczy się na pamięć dorobku wielkiego pisarza - mówi jeden z nich. - Taki jest cel naszego życia. Ja jestem w trakcie zapamiętywania dzieł zebranych Gofida Letterkerla. On nadal pisze, więc jestem, że tak powiem, niedokończony ${ }^{11}$.

${ }^{11}$ Walter Moers, Miasto Śniących Książek, trans. Katarzyna Bena (Wrocław: Wydawnictwo Dolnośląskie, 2004), 208. 
Inny natomiast dodaje:

Ja jestem kompletny. Ojahnn Golgo von Fontheweg umarł dziewięćset lat temu. A napisał siedemdziesiąt dwie powieści, ponad trzy tysiące wierszy, czterysta pięćdziesiąt sztuk teatralnych, a w wielu innych dyscyplinach literackich pozostawił wartościowe rzeczy. Muszę stale odświeżać swoją pamięććc.

Buchlingi mówią o sobie jak o książkach. One również przeistaczają się w dzieła danego autora. W przeciwieństwie jednak do ludzi z powieści Bradbury'ego robią to z czystej pasji. Nauka tekstów literackich to ich marzenie, życiowa misja. Ta trudna, katorżnicza praca jest jednak świadomym wyborem. Buchnlingi nie muszą ocalać niczego od zapomnienia, bronić dorobku literackiego Camonii. Uksiążkowienie odbywa się tutaj niejako na ich własną prośbę. Ich księgozbiór nie jest w żaden sposób wybrakowany czy niekompletny, przeciwnie - istoty te posiadają jedną z najbogatszych bibliotek tamtego świata. Nieustannie mogą z niej korzystać, by się doszkalać, i oczywiście to czynią. Nie znajdują się jednak pod żadną zewnętrzną presją. Uksiążkawiają się, bo tego chcą - w ten sposób mogą poczuć się spełnione.

Buchlingi nie są jedynymi przykładami żywych książek, jakie w swojej powieści tworzy Moers. Na kartach Miasta Śniących Ksiażek pojawia się bowiem jeszcze niejaki Król Cieni - niegdyś wybitny literat, największy z wielkich talentów poetyckich, który pod wpływem czarnej magii został przemieniony w żywą księgę. Ta transformacja była jednak całkowicie różna od odpisywanych powyżej. W tym wypadku bowiem przeistoczeniu ulega fizyczność postaci. Ciało Króla Cieni zostaje poddane takim zabiegom, jakim w średniowieczu poddawano materiały, z których tworzono kodeksy: oczyszczono je i obgotowano, pokryto różnego rodzaju smarowidłami, a finalnie także papierem. Efekt tych starań Moers opisuje następująco:

Stało tam stworzenie od stóp do głów składające się z papieru. Jedyną rzeczą przypominającą w nim człowieka był kształt jego ciała. Ręce, nogi, głowa, korpus, nawet twarz - wszystko to było na swoim miejscu, jednak składało się z niezliczonych warstw prastarego pożółkłego papieru. Z tysięcy skrawków pokrytych tymi samymi dziwacznymi runami, których śladem podążałem w labiryncie. A to, co w półmroku wziąłem za zęby korony, było obdartymi końcówkami papierowych skrawków, z których uformowano tę istotę. Gdyby nawet rzeźba z kamienia lub brązu ożyła, nie przeraziłaby mnie tak, jak ten olbrzymi twór z papieru, który powoli zmierzał w moją stronę $e^{13}$.

To jeszcze jeden interesujący aspekt motywu żywej księgi. Ktoś, kto zachował swoją tożsamość i pamięć, ale stracił fizyczność - zmienił się w potwora zbudowanego z kleju, papieru i run. Uksiążkowienie stało się dla Króla Cieni

\footnotetext{
${ }^{12}$ Ibidem.

${ }^{13}$ Ibidem, 346.
} 
przekleństwem. To nie książka zaklęta w ludzką postać, ale odwrotnie - człowiek wtłoczony w formę księgi. Kolejna wariacja na temat motywu żywego księgozbioru.

Wątek fizycznego przeistoczenia się w wolumin - choć w nie tak drastycznym stopniu jak w Mieście Śniących Ksiażek - pojawia się również w powieści Thomasa Whartona Salamandra. Dzieło opowiada o przygodach Nicholasa Flooda - wybitnego drukarza - który próbuje podołać zadaniu stworzenia nieskończonej książki. Podczas swoich podróży, w Aleksandrii, natrafia on na Legendę o Seszat, a w niej na motyw żywego księgozbioru. Oto gdy Wielkiej Bibliotece w Aleksandrii groziło zniszczenie wszystkich zbiorów, jeden z jej sędziwych pracowników wpadł na pomysł ocalenia przynajmniej treści przechowywanych dzieł:

Bibliotekarz zwołał wszystkich asystentów, wszystkich skrybów, kopistów i introligatorów. Sprowadziwszy specjalistów od tatuaży wyposażonych w kole jeżówki i farbę z olejku akacji, bibliotekarz rozkazał, by tekst każdej książki wytatuowano na ciałach mężczyzn. Tylko te części ciała, których nie zakrywało odzienie, pozostały nietknięte. Dyktowanie i przepisywanie zabrało wiele dni. Jednorazowo można było skopiować tylko mały fragment, gdyż ból był straszny i sprawiał, że mężczyźni skręcali się i trzęśli, niwecząc delikatną pracę artystów ${ }^{14}$.

Niestety cały ów trud poszedł na marne. Po wykryciu spisku kolejnych wytatuowanych bibliotekarzy wyłapywano i zabijano, a ich skóry rzucano w ogień. Z rzezi udało się ujść tylko Seszat, na której ciele przepisano traktat Hermesa o sztuce nieumierania. Przed jej śmiercią tekst przeniesiono na jednego z jej uczniów. Od tego czasu miał on być przekazywany w ten sposób z pokolenia na pokolenie.

W Salamandrze więc materiałem, na jaki kopiuje się księgi, nie są ludzkie umysły, lecz skóry. Uksiążkowieniu podlegają tutaj wyłącznie ciała i choć wiąże się to z ogromnym fizycznym bólem, tożsamość jednostki, która przeistacza się w księgę, wydaje się niezagrożona. W tym wypadku istotna okazuje się jej zewnętrzna powłoka. Od bibliotekarzy nie wymagano uczenia się niczego na pamięć. Wybrano sposób pozornie pewniejszy, gwarantujący, że żadne wersy nie zostaną zapomniane, żaden tekst nie przepadnie w odmętach ułomnej pamięci. Słowo w pewien przewrotny sposób przeistoczyło się w ciało. Aleksandryjscy bibliotekarze zdecydowali się na nośnik materialny. Niestety okazał się on zawodny, a wytatuowane na skórze litery pozwoliły bez większych kłopotów wyłapać i unicestwić żywe księgi. Z ogromnych zbiorów Wielkiej Biblioteki, wedle legendy, ostało się tylko jedno dzieło.

${ }^{14}$ Thomas Wharton, Salamandra, trans. Jerzy Kozłowski (Poznań: Dom Wydawniczy Rebis, 2002), 166. 


\section{Rzeczywiste żywe biblioteki}

Choć wszystkie przytoczone w powyższych akapitach przykłady wydają się abstrakcyjne, żywa biblioteka nie jest wyłącznie owocem pisarskiej wyobraźni. Posiada także swoje rzeczywiste realizacje, które w dużym stopniu różnią się od literackich pomysłów. Echa tego motywu możemy odnaleźć choćby w zorganizowanej w 2012 roku podczas Warszawskich Targów Dobrej Książki akcji Reading is a fashion. Jej celem było połączenie odrębnych sfer - czytania i mody. Wydarzenie składało się z dwóch części - wystawy fotografii Anny Powierży pod tytułem Parfume zainspirowanej słynną powieścią Süskinda - oraz konkursu dla młodych projektantów. Jego uczestnicy mieli za zadanie przygotować kreacje nie tylko nawiązujące do dzieł literackich, ale także wykonane z materiałów wykorzystywanych w księgarstwie i introligatorstwie - przede wszystkim papieru. Wśród wyróżnionych projektów znajdziemy stroje czerpiące z takich utworów jak Piękna i bestia, Carmen, Królowa Śniegu, Nie kończąca się historia, Tańcząca Żmija... Przykładowo, ostatnia z wymienionych pozycji, odwołująca się do wiersza Charles'a Baudelaire'a, była grafitową krótką sukienką o długich rękawach „uszytą” z połyskującego papieru. Tworzyły ją nachodzące na siebie, ostro zakończone płytki - przypominające tyleż łuski, co ostrza - które sprawiały, że kreacja mogła wywoływać skojarzenia ze zbroją łuskową. Ze stroju aż bił złowrogi, kuszący erotyzm, tak charakterystyczny dla twórczości francuskiego poety. Autorce - Nicol Grochowskiej - za pomocą stosunkowo prostych środków udało się więc nawiązać i do tytułowej żmii (lśniącej, czarnej, zmysłowej, o włosach odurzających jak las), i do atmosfery całego tomiku, w którym liryk się znajdował: przypominające ostro zakończone płatki kwiatów zdobienia, mroczna stylistyka, wzbudzająca tyleż zachwyt, co lęk.

Na podobnych konceptach opierały się także inne, biorące udział w konkursie, projekty. Ich autorzy za pomocą dostępnych środków próbowali fizycznie upodobnić je do książek i jednocześnie nawiązać do dzieł literackich, do których się odwołują. Suknia zainspirowana opowiadaniem $J a$, robot Izaaka Astimova jest kanciasta i ma metaliczną barwę. Kreacje czerpiące z Królowej Śniegu są białe, a zdobią je wycięte z papieru płatki śniegu. Carmen to krwistoczerwona mini opasana papierowymi różami... Każdy z tych projektów w jakiś sposób łączy ze sobą światy mody i czytelnictwa. Książki stają kreacjami, a kreacje książkami. W kontekście żywych bibliotek warto jednak zauważyć, że, noszące opisywane suknie modelki w czasie pokazu przemieniają się w przedmioty do czytania. Może nie składa się tutaj liter, a rozszyfrowuje ukryte w strojach subtelne symbole, lecz to również stanowi akt lektury. Powstałe w ramach opisywanego konkursu projekty, założone na ciała modelek, moglibyśmy więc uznać za pewien specyficzny rodzaj żywej biblioteki, w której choć na kilka chwil człowiek zmienia się w księgę.

Inną, znacznie bardziej rozbudowaną, realizacją motywu żywej biblioteki jest projekt Human Library. Stanowi on pokłosie działalności duńskiej organizacji 
Stop przemocy, która w 2000 roku jako pierwsza powołała do życia ludzki księgozbiór. Pomysł trafił na bardzo podatny grunt i przez ostatnie kilkanaście lat idea ta rozprzestrzeniała się stosunkowo szybko: obecnie jest realizowana w czterdziestu pięciu krajach na całym świecie, w tym w Polsce. Tak duża popularność zaowocowała stworzeniem wspomnianej Human Library, a więc międzynarodowej organizacji zrzeszającej żywe biblioteki z całego świata. Jej celem nie jest jednak promocja czytelnictwa czy ratowanie dziedzictwa literackiego ludzkości, a szeroko rozumiana walka $z$ wykluczeniami i dyskryminacją oraz ochrona praw człowieka. Woluminami w tym specyficznym księgozbiorze są ludzie, wyróżniający się w jakiś sposób na tle zbiorowości, której są częścią - przez swoje pochodzenie, kolor skóry, orientację seksualną, przeszłość. Przykładowo w katalogu wrocławskiej żywej biblioteki możemy odnaleźć takie pozycje, jak lesbijka, trzeźwiejący alkoholik, niesłyszący, były więzień czy schizofrenik. Użycie słowa „katalog” w tym kontekście jest jak najbardziej uzasadnione, ponieważ członkowie tego oryginalnego księgozbioru zostali skatalogowani, a każdy z nich opatrzony jest krótką informacyjną notatką, zachęcającą do wypożyczenia. Na przykład w opisie muzułmanina możemy przeczytać:

Jestem jak klocki Lego - każda część mojej kultury, historii składa się na to, kim jestem. A jestem jednocześnie Tunezyjczykiem i Polakiem, muzułmaninem i imigrantem. Piękne jest to, że wszystkie te części mojej tożsamości wzajemnie się przenikają, bo z każdą z nich wiele mnie łączy. Bardzo podziwiam ludzi, którzy potrafią określić się jednym słowem, tak jednoznacznie, bez wątpliwości i sprzeczności, powiedzieć kim są, dla mnie to niemożliwe ${ }^{15}$.

Członków żywej biblioteki upodabnia się więc do prawdziwych książek. Mają swój tytuł, opis, ich zbiór podczas danej edycji wydarzenia nazywa się półką. Uczestnicy, chcąc się z nimi zapoznać, muszą się zarejestrować, a więc założyć kartę biblioteczną. Gdy istnieje duża szansa, że temat danej książki będzie cieszył się popularnością, tworzy się jego drugi egzemplarz, czyli zaprasza do ludzkiej biblioteki kolejną osobę o podobnych doświadczeniach. Udzielający się w wydarzeniu wolontariusze to bibliotekarze, a osoby pomagające przełamać bariery językowe - tłumacze... Co jednak najważniejsze - żywe księgi można wypożyczyć i czytać ${ }^{16}$. Z tym że po raz kolejny lektura nie opiera się tutaj na składaniu liter w słowa, a słów w zdania, lecz na szczerej, otwartej rozmowie. Jak możemy przeczytać na stronie internetowej wrocławskiej instytucji:

Książka w Żywej Bibliotece ma szczególne zadanie: jej rola polega przede wszystkim na szczerej rozmowie z czytelnikiem, który zdecydował się na jej wypożyczenie. To spotkanie ma pomóc uczestnikowi w przełamaniu stereotypu i uprzedzeń względem grupy, którą

${ }^{15}$ Muzutmanin, http://zywabiblioteka.pl/?page_id=130 (acc. 19.01.2018).

${ }^{16}$ Dorota Mołodyńska-Küntzel, Podręcznik dla osób organizujących Żywą Bibliotekę (Wrocław: Żywa Biblioteka Polska, 2016). 
książka reprezentuje. [...] Rolą książki nie jest narzucanie swojego stylu życia, światopoglądu czy sposobu myślenia. Rozmowa z czytelnikiem opiera się o dialog i wzajemnie zrozumienie, przyczyniając się jednocześnie do walki z uprzedzeniami i dyskryminacją ${ }^{17}$.

Wypożyczane żywe książki mają poprzez dialog uczyć tolerancji i zrozumienia dla inności, przyczyniać się do jej akceptacji. Pełnią taką samą funkcję, jak książki tradycyjne - poszerzają horyzonty, przekazują wiedzę, oswajają z innością, prezentują rożne światopoglądy. Oczywiście, nie możemy obchodzić się z nimi jak ze zwyczajnymi woluminami: wziąć ich w dłonie, usiąść w fotelu, delektować się kolejnymi rozdziałami, a po lekturze odłożyć na półkę. Jeśli jednak zgodzimy się, że czytanie to dialog, niewątpliwie w jakimś sensie je przeczytamy. Obędzie się to jednak w zupełnie inny sposób niż podczas spotkania z buchlingami bądź ludzkimi księgami z powieści Bradbury'ego. Tam mieliśmy do czynienia z czymś na wzór chodzących i oddychających nośników danych, na których zapisano dzieła literackie. Tutaj treścią książki staje się jednostkowa biografia. Indywidualne przeżycia, wspomnienia, przemyślenia i poglądy przemieniają się w historię do opowiedzenia. Podmiotowość nie jest w tym wypadku zawłaszczana przez utwór, ale sama się nim staje. Owszem, ludzkie ciało stanowi obwolutę, jest okładką księgi, ale wypełnia ją już nie powieść czy poemat, lecz osobista biografia. W przypadku przytaczanych powyżej literackich pomysłów żywe książki zrzekały się swojej osobowości na rzecz tożsamości danego autora. Członkowie ludzkich księgozbiorów zrzeszonych w organizacji Human Library zachowują swoją podmiotowość i to z niej czynią treść książki. Sami są sobie autorami, redaktorami, korektorami, zecerami, introligatorami... Nieustannie pracują nad opowiadaną przez siebie historią, która przecież podczas każdego wypożyczenia musi być nieco inna. Jej kształt zależy wszak od humoru, fizycznej i psychicznej kondycji czy dyspozycji dnia danej żywej książki. W końcu ich głównym celem nie jest przechowywanie zagrożonych tekstów, ocalanie ich od zapomnienia. One nie ratują żadnych publikacji od tragicznego końca w płomieniach, nie próbują też poskładać w jakąś całość spopielonej biblioteki, kolekcjonować szczątków dawnego dziedzictwa. Same w sobie są oryginalnymi, pełnymi dziełami. Ich najważniejszym celem jest dialog, przełamywanie granic i budowanie płaszczyzn porozumienia pomiędzy różniącymi się ludźmi.

Uksiążkowienie polega tu więc nie na nauczeniu się jakiegoś tekstu na pamięć bądź przeistoczeniu się w istniejące już dzieło literackie, ale na potraktowaniu własnego życia jako wkładu książki - jej wnętrza, treści. Zamienieniu go na opowieść i dzieleniu się nią z tymi, których zainteresowała. To sytuacja zupełnie odwrotna niż w przypadku pisarskich pomysłów. W tym miejscu pojawia się pytanie, czy możemy tu jeszcze mówić o księgach. Wydaje się, że tylko w pewnym bardzo ogólnym sensie. O ile bohaterów powieści Bradbury'ego czy Moersa moglibyśmy jeszcze scharakteryzować jako bardzo specyficzne audiobooki,

${ }^{17} \dot{Z}$ ywe książki, http://zywabiblioteka.pl/?page_id=54 (acc. 19.01.2018). 
o tyle członkowie rzeczywistych żywych księgozbiorów to raczej luźna wariacja na temat samej idei księgi, gra z jej konwencją i narosłą wokół niej tradycją.

Warto zwrócić uwagę także na kwestię organizacji kolejnych edycji żywej biblioteki. Pomysłodawcy stawiają tutaj na różnorodność i zdecydowanie sprzeciwiają się gromadzeniu tematycznych księgozbiorów, w których widzą duże pole do nadużyć:

Tematem Żywej Biblioteki jest jednak różnorodność i każdy, kto doświadcza konsekwencji stereotypów i uprzedzeń w danej społeczności, powinien mieć możliwość zostania Żywą Książką. Żywa Biblioteka ma być narzędziem zmiany społecznej - jeśli używamy jej tematycznie, nie konfrontujemy czytelników z tym, co jest dla nich trudne i spotkanie zamienia się w wymianę poglądów ${ }^{18}$.

Zbiór żywych książek jest więc nie tylko różnorodny, ale także otwarty, na swój sposób płynny. Jego kształt zależy w dużej mierze od stereotypów, jakie obecne są w danej społeczności, w danym okresie. O ile, przykładowo, kilka lat temu duża liczba wypożyczeń była udziałem osób homoseksualnych, o tyle obecnie dziś znacznie większą popularnością wśród czytelników cieszą się muzułmanie oraz uchodźcy, którzy dziś niezwykle często padają ofiarami stereotypizacji. Ów otwarty charakter nie oznacza jednak, że ludzką książką może być każdy. Kryteria ich doboru są ściśle określone i zależą nie tylko od miejsca, w którym zostanie zorganizowana żywa biblioteka (możliwości lokalowe, stereotypy, z jakimi zmaga się dana społeczność), ale także indywidualnych cech danej osoby. Tytułem w tym księgozbiorze nie może zostać osoba, której działalność ma charakter misyjny, niezgodny z prawem, komercyjny, polityczny czy niebezpieczny dla zdrowia. Ludzką księgą może być wyłącznie ktoś pełnoletni i świadomy swojej inności, kto zamknął w swoim życiu pewien epizod i jest $w$ stanie opowiadać o nim swobodnie oraz z właściwym dystansem, bez nadmiernych emocji. Należy przy tym pamiętać, że żywa biblioteka nie stanowi dla nikogo swoistej psychoterapii. Jej celem jest walka z uprzedzeniami i stereotypami. Jest to spora różnica w stosunku do powieści Bradbury'ego czy Moersa, w których członkiem ludzkiego księgozbioru mógł zostać każdy, kto miał taką wolę, a w przypadku 451 stopni także odrobinę koniecznej odwagi.

Spoglądając na kwestie organizacyjne Human Library od strony praktycznej, należy wspomnieć, że minimalna, gwarantująca różnorodność liczba żywych książek wchodzących w skład katalogu podczas danego wydarzenia wynosi pięć. Kolejne edycje żywych bibliotek mogą trwać od jednego do kilku dni i być zlokalizowane w najróżniejszych przestrzeniach: szkołach, otwartych plenerach, instytucjach państwowych, lokalach prywatnych (pubach, kawiarniach), na festiwalach, a nawet $\mathrm{w}$ środkach transportu publicznego. Zależnie od tego, czy liczba czytelników jest ograniczona czy nie, możemy wyróżnić otwarte i zamknięte (dedykowane) żywe biblioteki.

${ }^{18}$ Dorota Mołodyńska-Küntzel, op. cit., 13. 


\section{Zakończenie}

Powyższy przegląd pokazuje, że ludzki księgozbiór jest nie tylko ciekawym literackim motywem, ale także posiada swoje rzeczywiste realizacje. Oba te aspekty jego funkcjonowania mogą stanowić obiekt zainteresowania literaturoznawców i bibliologów, ale także socjologów czy filozofów. Omawiane zagadnienie obrazuje jednocześnie, jak szeroko i nieszablonowo jest obecnie rozumiane pojęcie biblioteki i przede wszystkim książki. Ta przestaje być postrzegana wyłącznie jako zszyty blok kartek. Co jakiś czas odsłania swoje kolejne formy takie jak, między innymi, ludzka księga. Wydaje się, że jej naukowa, wieloaspektowa analiza pozwoli spojrzeć pod innym kątem nie tylko na sam termin „książka”, ale również na funkcje, jakie może pełnić w dzisiejszym świecie biblioteka oraz wyzwania, które przed nią stoją. Te zdają się wybiegać daleko poza stereotypowe gromadzenie, katalogowanie i udostępnianie lektur.

\section{Bibliografia}

Bednarska-Ruszajowa, Krystyna. Biblioteki w literaturze polskiej. Kraków: Wydawnictwo Uniwersytetu Jagiellońskiego, 2006.

Bednarska-Ruszajowa, Krystyna. „Światowe badania nad opisami bibliotek w utworach literackich”. In Biblioteki i książki w literaturze, ed. Krystyna Bednarska-Ruszajowa. Kraków: Wydawnictwo Uniwersytetu Jagiellońskiego, 1998, 9-54.

Borges, Jorge Luis. „Biblioteka Babel”. In Fikcje, trans. Kazimierz Piekarec, Andrzej Sobol-Juszczykowski. Warszawa: Państwowy Instytut Wydawniczy, 1972, 65-73.

Bradbury, Ray. 451 stopni Fahrenheita, trans. Iwona Michałowska-Gabrych. Warszawa: Solaris, 2008.

Eco, Umberto. O bibliotece, trans. Adam Szymanowski. Warszawa: Świat Książki, 2007. Kałążny, Jerzy. „Motyw biblioteki w literaturze”. Biblioteka, no. 2 (1998): 5-14.

Kotuła, Sebastian. Komunikacja Bibliologiczna wobec World Wide Web, rozprawa doktorska. Warszawa, 2012, http://depotuw.ceon.pl/bitstream/handle/item/189/Komunikacja\% 20ibliologiczna\%20wobec\%20World $\% 20$ Wide $\% 20$ Web.pdf? sequence $=1$ (acc. 05.01. 2018).

Kowalska, Marzena. „Kształtowanie wizerunku biblioteki w literaturze pięknej”. In Ksztattowanie wizerunku biblioteki, ed. Maria Czyżewska. Białystok: Wydawnictwo Wyższej Szkoły Ekonomicznej w Białymstoku, 2007, 105-132.

Moers, Walter. Miasto Śniacych Ksiązek, trans. Katarzyna Bena. Wrocław: Wydawnictwo Dolnośląskie, 2004.

Mołodyńska-Küntzel, Dorota. Podręcznik dla osób organizujących Żywa Bibliotekę. Wrocław: Żywa Biblioteka Polska, 2016.

Wharton, Thomas. Salamandra, trans. Jerzy Kozłowski. Poznań: Dom Wydawniczy Rebis, 2002. 